\title{
PEMBANGUNAN PENDIDIKAN MERDEKA BELAJAR (TELAAH METODE PEMBELAJARAN)
}

\author{
Muhammad Yamin ${ }^{1}$, Syahrir $^{2}$ \\ STKIP Harapan Bima ${ }^{1}$, Universitas Pendidikan Mandalika ${ }^{2}$ \\ syahrirmandala85@gmail.com
}

\begin{abstract}
Absrak. Artikel ini menelaah metode pembelajaran dalam pembangunan Pendidikan Merdeka Belajar. Pendidikan Merdeka Belajar merupakan respon terhadap kebutuhan sistem pendidikan pada era Revolusi Industri 4.0. Di era Revolusi Industri 4.0 kebutuhan utama yang ingin dicapai dalam sistem pendidikan atau lebih khusus dalam metode pembelajaran yaitu siswa atau peserta didik yaitu penguasaan terhadap literasi baru. Literasi baru tersebut yaitu. Pertama, literasi data. Kedua, literasi teknologi. Terakhir, literasi manusia. Selain itu, dalam sistem Pendidikan Merdeka Belajar tetap mengutamakan juga pendidikan karakter. Artikel ini menggunakan penelitian pustaka (library research). Dengan sumber data dari jurnal, laporan hasil penelitian, majalah ilmiah, surat kabar, buku yang relevan, hasil-hasil seminar, artikel ilmiah yang belum dipublikasi, narasumber, surat-surat kepustakaan, vidio grafik, dan sebagainya. Maka dalam penelitian ini, metode pembelajaran di era Revolusi Industri 4.0 dapat menentukan kesuksesan pembelajaran. Dan metode yang digunakan beragam, namun dalam sistem pendidikan merdeka belajar metode Blended Learning sangat ideal sebagai metode pembelajaran. Metode Blended Learning yaitu menggabungkan keunggulan pembelajaran yang dilakukan secara tatap-muka dan secara virtual. Dalam penelitian ini menguatkan teori dari Peter Fisk tentang tren kecenderungan pendidikan pada era industri 4.0.
\end{abstract}

\section{Keyword: Merdeka Belajar, Metode Pengajaran, Blended Learning}

\section{ENDAHULUAN}

Era revolusi industri 4.0 memiliki tantangan sekaligus peluang bagi lembaga pendidikan. Syarat maju dan berkembang lembaga pendidikan harus memiliki daya inovasi, dan dapat berkolaborasi. Jika tidak mampu berinovasi dan berkolaborasi, maka akan tertinggal jauh ke belakang. Namun jika sebaliknya, lembaga pendidikan akan mampu menciptakan Sumber Daya Manusia (SDM) yang dapat memajukan, mengembangkan, dan mewujudkan cita- cita bangsa yaitu membelajarkan manusia. Menjadikan manusia pembelajar bukan hal mudah seperti membalikkan telapak tangan. Lembaga pendidikan harus mampu menyeimbangkan sistem pendidikan dengan perkembangan zaman. Di era Revolusi Industri 4.0, sistem pendidikan diharapkan dapat mewujudkan perserta didik memiliki keterampilan yang mampu berfikir kritis dan memecahkan masalah, kreatif dan inovatif serta ketrampilan komunikasi dan kolaborasi. Juga keterampilan mencari, mengelola dan menyampaikan informasi serta trampil menggunakan informasi dan teknologi sangat dibutuhkan (Lihat, Eko Risdianto, 2019 : 4).

Di era Revolusi Industri 4.0 lembaga pendidikan tidak hanya membutuhkan literasi lama yaitu membaca, menulis, dan menghitung, akan tetapi juga membutuhkan literasi baru. Literasi baru yang dibutuhkan oleh lembaga pendidikan dapat dibagi tiga yaitu. Pertama, literasi data. Literasi ini merupakan kemampuan untuk membaca, menganalisis dan menggunakan informasi (big data) di dunia digital. Kedua, literasi teknologi. Literasi ini memahami cara kerja mesin, aplikasi teknologi (Coding Artificial Intelligence \& Engineering Principles). Terakhir, literasi manusia. Literasi berupa penguatan humanities, komunikasi, dan desain. Berbagai aktivitas literasi tersebut dapat dilakukan oleh siswa dan guru.

Menteri Pendidikan dan Kebudayaan (Kemendikbud) Nadiem Anwar Makarim saat berpidato pada acara Hari Guru Nasional (HGN) tahun 2019 mencetuskan konsep 
"Pendidikan Merdeka Belajar". Konsep ini merupakan respons terhadap kebutuhan sistem pendidikan pada era revolusi industri 4.0. Nadiem Makarim menyebutkan merdeka belajar merupakan kemerdekaan berfikir. Kemerdekaan berfikir ditentukan oleh guru (Tempo.co, 2019). Jadi kunci utama menunjang sistem pendidikan yang baru adalah guru.

Nadiem Makarim (2019) mengatakan guru tugasnya mulia dan dan sulit. Dalam sistem pendidikan nasional guru ditugasi untuk membentuk masa depan bangsa namun terlalu diberikan aturan dibandingkan pertolongan. Guru ingin membantu murid untuk mengejarkan ketertinggalan di kelas, tetapi waktu habis untuk mengejarkan administrasi tanpa manfaat yang jelas. Guru mengetahui potensi siswa tidak dapat diukur dari hasil ujian, namun guru dikerjar oleh angka yang didesak oleh berbagai pemangku kepentingan. Guru ingin mengajak murid ke luar kelas untuk belajar dari dunia sekitanya, tetapi kurikulum yang begitu pada menutup petualangan. Guru sangat frustasi bahwa di dunia nyata bahwa kemampuan berkarya dan berkolaborasi menentukan kesuksesan anak, bukan kemampuan menghafal. Guru mengetahui bahwa setiap murid memiliki kebutuhan berbeda, tetapi keseragaman mengalahkan keberagaman sebagai prinsip dasar birokrasi. Guru ingin setiap murid terinspirasi, tetapi guru tidak diberi kepercayaan untuk berinovasi (Nadiem Makarim dalam Kemendikbud.go.id, 2019).

R. Suyanto Kusumaryono (2019) menilai bahwa konsep "Merdeka Belajar" yang dicetuskan oleh Nadiem Makarim dapat ditarik beberapa poin (R. Suyanto Kusumaryono dalam Kemendikbud.go.id, 2019). Pertama, konsep "Merdeka Belajar" merupakan jawaban atas masalah yang dihadapi oleh guru dalam praktik pendidikan. Kedua, guru dikurangi bebannya dalam melaksanakan profesinya, melalui keleluasaan yang merdeka dalam menilai belajar siswa dengan berbagai jenis dan bentuk instrumen penilaian, merdeka dari berbagai pembuatan administrasi yang memberatkan, merdeka dari berbagai tekanan intimidasi, kriminalisasi, atau mempolitisasi guru.

Ketiga, membuka mata kita untuk mengetahui lebih banyak kendala-kendala apa yang dihadapi oleh guru dalam tugas pembelajaran di sekolah, mulai dari permasalahan penerimaan perserta didik baru (input), administrasi guru dalam persiapan mengajar termasuk RPP, proses pembelajaran, serta masalah evaluasi seperti USBN-UN (output). Keempat, guru yang sebagai garda terdepan dalam membentuk masa depan bangsa melalui proses pembelajaran, maka menjadi penting untuk dapat menciptakan suasana pembelajaran yang lebih heppy di dalam kelas, melalui sebuah kebijakan pendidikan yang nantinya akan berguna bagi guru dan siswa. Terakhir, dicetuskannya konsep "Merdeka Belajar" pada saat Nadiem Makarim memberikan pidato pada acara Hari Guru Nasional (HGN) tersebut, diasumsikan tidak lagi menjadi gagasan melainkan lebih pada sebuah kebijakan yang akan dilaksanakan.

Kesimpulan dari konsep merdeka belajar merupakan tawaran dalam merekonstruksi sistem pendidikan nasional. Penataan ulang sistem pendidikan dalam rangka menyongsong perubahan dan kemajuan bangsa yang dapat menyesuaikan dengan perubahan zaman. Dengan cara, mengembalikan hakikat dari pendidikan yang sebenarnya yaitu pendidikan untuk memanusiakan manusia atau pendidikan yang membebaskan. Dalam konsep merdeka belajar, antara guru dan murid merupakan subyek di dalam sistem pembelajaran. Artinya guru bukan dijadikan sumber kebenaran oleh siswa, namun guru dan siswa berkolaborasi penggerak dan mencari kebenaran. Artinya posisi guru di ruang kelas bukan untuk menanam atau menyeragamkan kebenaran menurut guru, namun menggali kebenaran, daya nalar dan kritisnya murid melihat dunia dan fenomena. Peluang berkembangnya internet dan teknologi menjadi momentum kemerdekaan belajar. Karena dapat meretas sistem pendidikan yang kaku atau tidak membebaskan. Termasuk mereformasi beban kerja guru dan sekolah yang terlalu 
dicurahkan pada hal yang administratif. Oleh sebabnya kebebasan untuk berinovasi, belajar dengan mandiri, dan kreatif dapat dilakukan oleh unit pendidikan, guru dan siswa.

Saat ini antara guru dan siswa memiliki pengalaman yang mandiri termasuk di lingkungan. Dan dari pengalaman yang ada tersebut akan didiskursuskan di ruang kelas dan lembaga pendidikan. Adaptasi sistem pendidikan di era Revolusi Industri 4.0 harus distimulasi dengan proses literasi baru tersebut. Siswa/peserta didik pada era industri 4.0 memiliki pengalaman yang padat dengan dunia digital atau visual saat ini. Dan tugas guru, kepala sekolah termasuk lembaga pendidikan dapat mengarahkan, memimpin, dan menggali daya kritis dan potensi siswanya.

Dalam proses pembelajaran dibangunkan ekosistem pendidikan yang memfasilitasi tumbuh dan berkembangnya nalar, karakter, inovasi, kemandirian, kenyamanan, dan keahlian siswa. Maka merdeka belajar dampat membentuk sumber daya yang unggul atau berkualitas untuk menuntaskan peluang pendidikan pada era Industri 4.0 dengan tujuan kemajuan bangsa dan negara. Berdasarkan uraian latar belakang dan masalah di atas, maka sangat perlu untuk meneliti dan mendalami metode pembelajaran dalam sistem pendidikan merdeka belajar. Dalam artikel ini akan menjawab pertanyaan penelitian, bagaimana metode pembelajaran dalam menunjang pembangunan pendidikan mereka belajar?

\section{TINJAUAN PUSTAKA}

Dalam artikel ini, penulis menggunakan teori perubahan sosial. Teori ini unuk menjawab pertanyaan peneltian tentang metode pemebelajaran dalam menunjang pembangunan pendidikan merdeka belajar. Teori perubahan sosial, didukung oleh tren kecenderungan pendidikan pada era industri 4.0 Peter Fisk.

Dalam teori perubahan sosial yang paling mendasar yaitu menjelaskan peran penting manusia terhadap terjadinya perubahan masyarakat. Perubahan itu terjadi sesuai dengan hakikat dan sifat dasar manusia yang selalu ingin melakukan perubahan, karena manusia memiliki sifat selalu tidak puas terhadap apa yang telah dicapainya, ingin mencari sesuatu yang baru untuk mengubah keadaan agar menjadi lebih baik sesuai dengan kebutuhannya (Nur Djazifah ER, 2012 : 3). Dengan berbekal akal-budi tersebut manusia memiliki tujuh kemampuan yang berfungsi untuk: menciptakan, mengkreasi,memperlakukan, memperbarui, memperbaiki, mengembangkan, dan meningkatkan segala hal dalam interaksinya dengan alam maupun manusia lainnya (Herimanto dan Winarno dalam $\mathrm{Nu}$ Nur Djazifah ER, 2012 : 3-4). Ketujuh kemampuan tersebut merupakan potensi yang dimiliki manusia untuk kepentingannya dalam upaya memenuhi kebutuhan hidupnya, yaitu mempertahankan dan meningkatkan derajat kehidupannya, mengembangkan sisi kemanusiaannya, dengan cara menciptakan kebudayaan (selanjutnya manusia juga mengkreasi, memperlakukan, memperbarui, memperbaiki, mengembangkan dan meningkatkan kebudayaan) (Nur Djazifah ER, 2012 : 4).

Kebudayaan yang dihasilkan melalui akal budi manusia sering menjadi pencetus terjadinya perubahan sosial. Artinya perubahan sosial tidak terlepas dari perubahan kebudayaan. Bahkan Kingsley Davis (2000) berpendapat bahwa perubahan sosial merupakan bagian dari perubahan kebudayaan. Adapun menurut PB Horton dan CL Hunt ( 1992 ), hampir semua perubahan besar mencakup aspek sosial budaya. Oleh karena itu dalam menggunakan istilah perubahan sosial dan perubahan budaya, perbedaan di antara keduanya tidak terlalu diperhatikan. Di samping itu, kedua istilah tersebut seringkali ditukar pakaikan; kadangkala digunakan istilah perubahan sosial - budaya ( sosiocultural change) agar dapat mencakup kedua jenis perubahan tersebut. Yang jelas perubahan - perubahan sosial dan kebudayaan mempunyai satu aspek yang sama yaitu kedua - duanya bersangkutpaut dengan suatu penerimaan cara-cara baru atau suatu perbaikan dalam cara suatu masyarakat memenuhi kebutuhan kebutuhannya (Nur Djazifah ER, 2012 : 4). 
Termasuk di dalam sistem pendidikan saat ini yaitu pada era revolusi industri 4.0. Pada saat ini, sistem pendidikan membutuhkan caracara baru atau membutuhkan ekosistem yang baru untuk mewujudkan perbaikan masyarakat atau menunjang kebutuhankebutuhan seperti sumber daya manusia yang berkualitas dan unggul. Peter Fisk (2019) mengatakan ada sembilan tren atau kecenderungan terkait dengan pendidikan 4.0 (Peter Fisk dalam Delepiter Lase, 2019 : 2930). Pertama, belajar pada waktu dan tempat yang berbeda. Siswa akan memiliki lebih banyak kesempatan untuk belajar pada waktu dan tempat yang berbeda. E-learning memfasilitasi kesempatan untuk pembelajaran jarak jauh dan mandiri. Kedua, pembelajaran individual. Siswa akan belajar dengan peralatan belajar yang adaptif dengan kemampuannya. Ini menunjukkan bahwa siswa pada level yang lebih tinggi ditantang dengan tugas dan pertanyaan yang lebih sulit ketika setelah melewati derajat kompetensi tertentu. Siswa yang mengalami kesulitan dengan mata pelajaran akan mendapatkan kesempatan untuk berlatih lebih banyak sampai mereka mencapai tingkat yang diperlukan. Siswa akan diperkuat secara positif selama proses belajar individu mereka. Ini dapat menghasilkan pengalaman belajar yang positif dan akan mengurangi jumlah siswa yang kehilangan kepercayaan tentang kemampuan akademik mereka. Di sini, guru akan dapat melihat dengan jelas siswa mana yang membutuhkan bantuan di bidang mana.

Ketiga, siswa memiliki pilihan dalam menentukan bagaimana mereka belajar. Meskipun setiap mata pelajaran yang diajarkan bertujuan untuk tujuan yang sama, cara menuju tujuan itu dapat bervariasi bagi setiap siswa. Demikian pula dengan pengalaman belajar yang berorientasi individual, siswa akan dapat memodifikasi proses belajar mereka dengan alat yang mereka rasa perlu bagi mereka. Siswa akan belajar dengan perangkat, program dan teknik yang berbeda berdasarkan preferensi mereka sendiri. Pada tataran ini, kombinasi pembelajaran tatap muka dan pembelajaran jarak jauh (blended learning), membalikkan ruang kelas dan membawa alat belajar sendiri (bring your own device) membentuk terminologi penting dalam perubahan ini.

Empat, pembelajaran berbasis proyek. Siswa saat ini harus sudah dapat beradaptasi dengan pembelajaran berbasis proyek, demikian juga dalam hal bekerja. Ini menunjukkan bahwa mereka harus belajar bagaimana menerapkan keterampilan mereka dalam jangka pendek ke berbagai situasi. Siswa sudah harus berkenalan dengan pembelajaran berbasis proyek di sekolah menengah. Inilah saatnya keterampilan mengorganisasi, kolaborasi, dan manajemen waktu diajarkan kepada peserta didik untuk kemudian dapat digunakan setiap siswa dalam karir akademik mereka selanjutnya.

Lima, pengalaman lapangan. Kemajuan teknologi memungkinkan pembelajaran domain tertentu secara efektif, sehingga memberi lebih banyak ruang untuk memperoleh keterampilan yang melibatkan pengetahuan siswa dan interaksi tatap muka. Dengan demikian, pengalaman lapangan akan diperdalam melalui kursus atau latihanlatihan. Sekolah akan memberikan lebih banyak kesempatan bagi siswa untuk memperoleh keterampilan dunia nyata yang mewakili pekerjaan mereka. Ini menunjukkan disain kurikulum perlu memberi lebih banyak ruang bagi siswa untuk lebih banyak belajar secara langsung melalui pengalaman lapangan seperti magang, proyek dengan bimbingan dan proyek kolaborasi.

Enam, interpretasi data. Perkembangan teknologi komputer pada akhirnya mengambil alih tugas-tugas analisis yang dilakukan secara manual (matematik), dan segera menangani setiap analisis statistik, mendeskripsikan dan menganalisis data serta memprediksi tren masa depan. Oleh karena itu, interpretasi siswa terhadap data ini akan menjadi bagian yang jauh lebih penting dari kurikulum masa depan. Siswa dituntut memiliki kecakapan untuk menerapkan pengetahuan teoretis ke angkaangka, dan menggunakan keterampilan mereka untuk membuat kesimpulan berdasarkan logika dan tren data. 
Tujuh, penilaian beragam. Mengukur kemampuan siswa melalui teknik penilaian konvensional seperti tanya jawab akan menjadi tidak relevan lagi atau tidak cukup. Penilaian harus berubah, pengetahuan faktual siswa dapat dinilai selama proses pembelajaran, dan penerapan pengetahuan dapat diuji saat siswa mengerjakan proyek mereka di lapangan.

Delapan, keterlibatan siswa. Keterlibatan siswa dalam menentukan materi pembelajaran atau kurikulum menjadi sangat penting. Pendapat siswa dipertimbangkan dalam mendesain dan memperbarui kurikulum. Masukan mereka membantu perancang kurikulum menghasilkan kurikulum kontemporer, mutakhir dan bernilai guna tinggi. Terakhir, mentoring. Pendampingan atau pemberian bimbingan kepada peserta didik menjadi sangat penting untuk membangun kemandiran belajar siswa. Pendampingan menjadi dasar bagi keberhasilan siswa, sehingga menuntut guru untuk menjadi fasilitator yang akan membimbing siswa menjalani proses belajar mereka

\section{METODE PENELITIAN}

Untuk jenis penelitian tentang "Pembangunan Pendidikan Merdeka Belajar : Telaah Metode Pembelajaran", penulis menggunakan penelitian pustaka (library research). Penelitian pustaka adalah penelitian yang teknik pengumpulan datanya dilakukan dengan cara membaca berbagai literatur yang berkaitan dengan informasi serta relevansi terhadap topik penelitian (Sukardi, 2010 : 3435). Sedangkan menurut Lexy J. Moleong penelitian pustaka dengan penelitian lapangan menggunakan pendekatan kualitatif yakni penelitian yang prosedurnya menghasilkan data deskriptif berupa kata-kata yang tertulis atau lisan dari orang-orang dan pelaku yang diamati (Lexy J.Moleong dalam Fandi Ahmad, 2015 : 147).

Adapun jenis penelitian pustaka yang dilakukan yaitu fi eld research, penelitian menggunakan tipe deskriptif yakni mendeskripsikan secara terperinci realitas atau fenomenafenomena dengan memberikan kritik atau penilaian terhadap fenomena tersebut. Pendekatan yang digunakan penulis dalam penelitian ini adalah pendekatan sosiologis. Pendekatan sosiologis digunakan untuk memecahkan masalah yang aktual dengan jalan mengumpulkan, menyusun, menganalisis serta mengklarifikikasikan data. Macam-macam sumber data dalam artikel antara lain yaitu jurnal, laporan hasil penelitian, majalah ilmiah, surat kabar, buku yang relevan, hasil-hasil seminar, artikel ilmiah yang belum dipublikasi, narasumber, surat-surat kepustakaan, vidio grafik, dan sebagainya.

\section{PEMBAHASAN}

DISKURSUS

METODE

PEMBELAJARAN PADA PENDIDIKAN MERDEKA BELAJAR

Pada bagian sesungguhnya menguraikan metode pembelajaran dalam merespon era Revolusi Industri 4.0. Karena pendidikan merdeka belajar merupakan respon terhadap era baru ini, maka sangat relevan untuk melihat data muktahir dan diskursus para scholar tentang metode pembelajaran. Diskursus oleh scholar yang fokus meneliti di Indonesia akan lebih dominan diuraikan oleh penulis. Namun satu kepastian dalam era Revolusi Industri 4.0 kebutuhan utama yang ingin dicapai dalam sistem pendidikan atau lebih khusus dalam metode pembelajaran yaitu siswa atau peserta didik yaitu penguasaan terhadap literasi baru.

Literasi baru tersebut yaitu. Pertama, literasi data. Literasi ini merupakan kemampuan untuk membaca, menganalisis dan menggunakan informasi (big data) di dunia digital. Kedua, literasi teknologi. Literasi ini memahami cara kerja mesin, aplikasi teknologi (Coding Artificial Intelligence \& Engineering Principles). Terakhir, literasi manusia. Literasi berupa penguatan humanities, komunikasi, dan desain. Berbagai aktivitas literasi tersebut dapat dilakukan oleh siswa dan guru. Dan sistem dan atau metode pembelajaran pada pendidikan merdeka belajar mempunyai target yang sama. Jika perserta didik atau siswa dapat mengusai literasi baru ini, maka akan menjadi sumber daya manusia yang berkualitas dan unggul dalam membangun masa depan Indonesia. 
Namun selain literasi baru, sistem pendidikan di era Revolusi Industri 4.0 tetap melakukan pembangunan karakter, seperti kejujuran, religius, kerja keras/tekun, tanggung jawab, adil, disiplin, toleran, dan lain-lain.

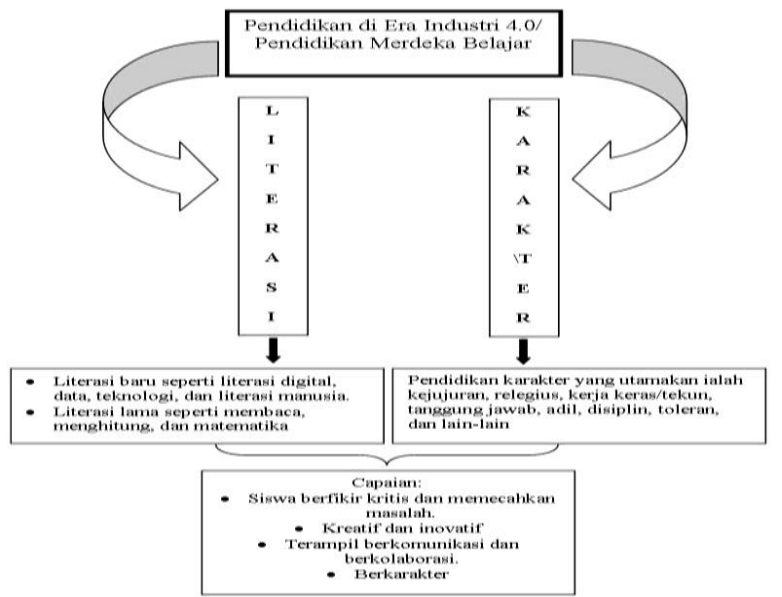

Gambar 1. Pendidikan Di Era Industri 4.0/Pendidikan Merdeka Belajar

Sumber : Diolah Oleh Penulis dari Berbagai

Literatur

Ada beberapa scholar yang telah meneliti sistem pembelajaran dalam merespon era Industri 4.0 di Indonesia. Hamidulloh Ibda dan E Rahmadi (2018), Muhammad Alfarizqi Nizamuddin Ghiffar, Eliza Nurisma, Cucu Kurniasih, dan Caraka Putra Bhakti (2018), Ayik Wulandari, Putri Handayani, dan Dody Rahayu Prasetyo (2019), Aprilia Riyana Putri dan Muhammad Alie Muzakki (2019), Eko Rusdianto (2019), Dan Delipiter Lase (2019). Scholar di atas dapat memberikan gambaran metode pembelajaran yang dapat digunakan dalam sistem pendidikan merdeka belajar.

Hamidulloh Ibda dan E Rahmadi (2018) menyebutkan bahwa dalam era Revolusi Industri 4.0 lembaga pemdidikan harus mengutakan literasi baru. Artikel yang ditulis Hamidulloh Ibda dan E Rahmadi menegaskan bahwa lembaga pendidikan tidak cukup menerapkan literasi lama (membaca, menulis, berhitung), tetapi harus menerapkan literasi baru (literasi data, literasi teknologi dan literasi sumber daya manusia atau humanisme). Selain itu, Hamidulloh Ibda dan E Rahmadi juga membahas tantangan dan peluang pendidikan di era Revolusi Industri 4.0. Penguatan literasi baru, guru menjadi kunci perubahan, yang didukung oleh revitalisasi kurikulum berbasis literasi dan penguatan peran guru yang memiliki kompetensi digital. Guru berperan membangun generasi berkompetensi, berkarakter, memiliki kemampuan literasi baru, dan keterampilan berpikir tingkat tinggi. Hamidulloh Ibda dan E Rahmadi mengatakan juga bahwa lembaga pendidikan sebagai dasar penentu kecerdasan intelektual, spiritual, dan emosional pada anak, harus memperkuat keterampilan literasi abad 21. Mulai aspek kreatif, pemikiran kritis, komunikatif, dan kolaboratif. Lembaga pendidikan harus memperkuat literasi baru dan revitalisasi kurikulum berbasis digital. Revitalisasi kurikulum mengacu pada lima nilai dasar dari peserta didik yang baik, yaitu ketahanan, kemampuan beradaptasi, integritas, kompetensi, dan peningkatan berkelanjutan. Pendidik harus menjadi guru digital, paham komputer, dan bebas dari penyakit akademis (Lihat Hamidulloh Ibda dan E Rahmadi, 2018: 1).

Artikel yang ditulis oleh Hamidulloh Ibda dan E Rahmadi hasil penelitianya di Guru Madrasah Ibtidaiyah, jadi fokusnya hanya pada lembaga pendidikan dasar Islam. Walaupun terfokus di lembaga pendidikan Islam, hasil penelitian ini disepakati oleh semua scholer tentang tantangan dan peluang lembaga pendidikan di era Revolusi Industri 4.0. Lihat juga tulisan Eko Rusdianto (2019), Delipiter Lase (2019). Namun kekurangan dalam artikel ini tidak membahas secara khusus metode pembelajaran yang harus diterapkan oleh lembaga pendidikan dan guru dalam sistem pembelajaran. Sehingga artikel ini masih secara umum.

Muhammad Alfarizqi Nizamuddin Ghiffar, Eliza Nurisma, Cucu Kurniasih, dan Caraka Putra Bhakti (2018) menjawab kekurangan dari riset Hamidulloh Ibda dan E Rahmadi. Mereka menawarkan model atau metode pembelajaran berbasis Blended Learning dalam era Revolusi Industri 4.0. Model Blended Learning merupakan penggabungan dari metode belajar yang offline (tatap muka, dan lain-lain) dengan metode pembelajaran yang online (e-learning). Secara khusus Muhammad Alfarizqi Nizamuddin Ghiffar, Eliza Nurisma, Cucu Kurniasih, dan Caraka 
Putra Bhakti menulis artikel ini secara khusus meningkatkan critical thinking. Dalam era Revolusi Industri 4.0 merupakan era dimana hidup manusia berorientasi pada teknologi, seperti penguasaan teknologi, dunia maya, big data, dan lain-lain. Hal ini dikarenakan permasalahan di era Revolusi Industri 4.0 lebih kompleks, dan manusia harus mampu bertahan dan mengatasi permsalahannya (Muhammad Alfarizqi Nizamuddin Ghiffar, Eliza Nurisma, Cucu Kurniasih, dan Caraka Putra Bhakti, 2018: 85).

Namun artikel ini hanya mementingkan dimensi literasi baru yaitu literasi teknologi, data, dan manusia dalam metode pembelajaran Blended Learning. Masalah yang kompleks akan menghinggapi manusia kedepan yaitu berkaitan dengan keterampilan dalam penguasaan teknologi, dunia maya, dan big data. Padahal masalah moral dan etika tetap menjadi masalah utama juga di era Revolusi Industri 4.0 atau masalah dalam pembangunan critical thinking. Jadi kekurangan dalam artikel yang ditulis oleh Muhammad Alfarizqi Nizamuddin Ghiffar, Eliza Nurisma, Cucu Kurniasih, dan Caraka Putra Bhakti mengesampingkan aspek atau dimensi pembangunan karakter dalam model pembelajaran.

Sedangkan Ayik Wulandari, Putri Handayani, dan Dody Rahayu Prasetyo (2019) menawarkan metode Education Mini Club (EMC) sebagai solusi dalam menghadapi tantangan pendidikan di era Revolusi Industri 4.0. Metode EMC yang ditawarkan oleh Ayik Wulandari, Putri Handayani, dan Dody Rahayu Prasetyo sebagai respon terhadap proses pembelajaran yang kurang sesuai dengan keadaan siswa yang tidak suka dengan metode pembelajaran yang monoton. Dari hasil pengamatannya di MTs $\mathrm{Nu}$ Ibtidaul Falah, ada peningkatan hasil belajar dengan menggunakan metode Education Mini Club (EMC). Data tersebut diperoleh dari hasil nilai pree test (sebelum di terapkan nya medode Educatin Mini Club (EMC) di bandingkan dengan nilai setelah di terapkanya metode EMC ini hasil nilai yang diperoleh lebih bagus setelah di terapkannya metode EMC. Sebelum di terapkannya ada beberapa siswa yang belum mncapai Kriteria Ketuntasan Minimum (KKM) yang di tetapkan pihak sekolah setelah di terapakan metode EMC ini siswa semua telah mencapai KKM (Ayik Wulandari, Putri Handayani, dan Dody Rahayu Prasetyo, 2019 : 51).

Riset yang dilakukan oleh Ayik Wulandari, Putri Handayani, dan Dody Rahayu Prasetyo mengamati Kriteria Ketuntasan Minimum (KKM) dengan menggunakan metode EMC pada pembelajaran Ilmu Pengetahuan Alam (IPA). Dalam sistem pendidikan di era Revolusi Industri 4.0 murid atau peserta didik diharuskan untuk menguasai literasi baru dan mencapai pembangunan karakter. Agar dapat mencapai kesuksesan pendidikan di era Revolusi Industri 4.0, yang menjadi kunci utamanya adalah guru dengan terlebih dahulu untuk mengusai literasi baru. Oleh sebab itu, dalam riset ini, ketuntasan yang menjadi indikator dalam penilainnya cenderung belum mensyaratkan sepenuhnya tantangan pendidikan di era Revolusi Industri 4.0. Dan penelitian ini sudah cukup memberikan masukan secara metodelogi model dan atau metode yang dapat digunakan dalam pembelajaran di era Revolusi Industri 4.0. Terutama menjawab tantangan model pembelajaran yang terlalu monoton atau tidak adanya inovasi.

Setelah diskursus pembangunan metode pembelajaran dalam pendidikan era Revolusi Industri 4.0, Aprilia Riyana Putri dan Muhammad Alie Muzakki (2019) menyempurnakan dengan menawarkan media pembelajaran. Dalam metode pembelajaran, media pembelajaran membuat peserta didik (siswa/mahasiswa) akan lebih mudah memahami apa yang di terangkan oleh guru maupun dosen dalam proses pembelajaran baik di dalam kelas maupun diluar kelas. Ada berbagai macam jenis media, seperti media cetak yaitu; buku, modul, lks dan juga media elektronik yaitu; video, audio, presentasi multimedia dan juga bisa menggunakan konten daring atau online. Di setiap akhir proses pembelajaran, setiap pendidik melakukan evaluasi pembelajaran untuk mengukur sejauh mana kemampuan siswa dalam memahami apa yang sudah diterangkan 
dengan berbagai macam cara, bisa dengan memberi kuis, presentasi secara berkelompok, test tertulis dan juga menggunakan media kahoot yaitu dengan cara memasukkan soal pilihan ganda ke aplikasi kahoot yang memang menggunakan fasilitas internet agar handphone siswa bisa terkoneksi langsung untuk menjawab kuis yang disajikan oleh pendidik melalui media kahoot tersebut. Para siswa bisa melihat hasilnya secara langsung dengan urutan peringkat. Ada dua tipe dalam menggunakan kahoot yaitu klasik dan mode. Pemanfaatan media kahoot untuk menghadapi revolusi industri 4.0 dalam dunia pendidikan sesuai karena hampir semua pendidik maupun siswa bisa menggunakan media kahoot dan dalam realisasinya mereka juga menggunakan internet sebagai alat untuk mencari referensi tambahan dalam proses belajar maupun mengajar baik untuk mencari informasi materi, audio dan video pembelajaran serta memanfaatkan aplikasi-aplikasi pendidikan yang tersedia secara gratis di play store yang digunakan dalam proses pembelajaran untuk meningkatkan proses pembelajaran yang mudah di fahami dan menarik serta menyenangkan (Aprilia Riyana Putri dan Muhammad Alie Muzakki, 2019).

Riset yang dilakukan oleh Aprilia Riyana Putri dan Muhammad Alie Muzakki tidak hanya menawarakan media pembelajaran. Namun kahoot tepatnya menjadi instrumen dalam metode pembelajaran. Jadi riset ini sesungguhnya menyimpulkan metode pembelajaran dalam era Revolusi Industri 4.0 yaitu menggunakan metode E-Learning. Walaupun tidak menyebut, e-learning secara langsung, namun aplikasi dan cara kahoot digunakan sebagai pelaksanaan metode pembelajaran e-learning (belajar online).

Dari diskurus scholer, metode pembelajaran di era Revolusi Industri 4.0 dapat menentukan kesuksesan pembelajaran. Dan metode yang digunakan beragam, dan dalam artikel ini pemangku kependingan sedapat mungkin menentukan metode pembelajaran yang dapat mencapai tujuan dari sistem pendidikan merdeka belajar. Oleh sebabnya, artikel ini menjadi reverensi dalam menepurnakan sistem pendidikan merdeka belajar, yang akan dijadikan sistem pendidikan yang baru di Indonesia. Langkah pemerintah untuk meneruskan kebijakan pendidikan merdeka belajar akan merombak kurikulum pendidikan dengan lebih menekankan pada konsep STEAM (Science, Technology, Engineering, the Arts, dan Mathematics), menyelaraskan kurikulum pendidikan nasional dengan kebutuhan industri di masa mendatang. Dan metode pembelajaran harus dapat merepresentasikan keberangaman yang ada di Indonesia. Agar capaian tujuan satuan pendidikan, yaitu menciptakan sumber daya manusia yang berkualitas dan unggul. Jika pendidikan meredeka belajar sudah benarbenar program yang baik, maka disini dibutuhkan ketegasan dan keberanian untuk mewujudkan dan menjalankan program program tersebut dengan baik. Jangan sampai program yang sudah tersusun dengan baik namun dalam pelaksanaannya hanya sebatas formalitas belaka (Eko Rusdianto, 2019 : 4).

\section{BLENDED LEARNING DAN ORIENTASI PENDIDIKAN}

Berdasarkan sembilan tren atau kecenderungan terkait dengan pendidikan di era Revolusi Industri 4.0 yaitu antara lain. Pertama, belajar pada waktu dan tempat yang berbeda. Kedua, pembelajaran individual. Ketiga, siswa memiliki pilihan dalam menentukan bagaimana mereka belajar. Empat, pembelajaran berbasis proyek. Lima, pengalaman lapangan. Enam, interpretasi data. Tujuh, penilaian beragam. Delapan, keterlibatan siswa. Terakhir, mentoring. Blended Learning merupakan metode pembelajaran yang digunakan dalam sistem pendidikan merdeka belajar. Blended learning disimpulkan juga dari berbagai riset dan perdebatan scholar dalam merespon sistem dan metode pembelajaran di era Revolusi Industri 4.0. Secara khusus, riset yang dilakukan oleh Muhammad Alfarizqi Nizamuddin Ghiffar, Eliza Nurisma, Cucu Kurniasih, dan Caraka Putra Bhakti (2018) akan disempurnakan dalam artikel ini.

Menerapkan konsep cara belajar yang aktif, inovatif, dan nyaman harus dapat mewujudkan perserta didik sesuai kebutuhan zaman atau era industri 4.0. Demi tercapainya 
tujuan pendidikan yaitu mewujudkan murid atau peserta didik yang berfikir kritis dan memecahkan masalah, kreatif dan berinovasi, terampil berkomunikasi dan berkolaborasi, dan berkarakter. Oleh sebab itu, dalam rencana pelaksanaan kegiatan belajar harus mampu melewati tantangan dan memanfaatkan peluang pendidikan di era Revolusi Industri 4.0. Dan guru menjadi kunci keberhasilan sistem pendidikan, oleh sebab itu harus dapat beradaptasi dengan sistem pendidikan yang baru agar memiliki kopetensi dan keterampilan. Penguatan literasi baru pada guru sebagai kunci perubahan, termasuk revitalisasi kurikulum berbasis literasi dan penguatan peran guru yang memiliki kompetensi digital. Maka metode Blended Learning sangat ideal sebagai metode pembelajaran di sistem pendidikan merdeka belajar. Karena antara penguasaan kopentesi literasi baru, sistem pengajaran harus tetap membangun karakter dengan mengkobinasikan metode-metode pengajaran yang konvensional, seperti tatap muka atau yang ditawarakan oleh Ayik Wulandari, Putri Handayani, dan Dody Rahayu Prasetyo (2019) yaitu metode Education Mini Club (EMC) sebagai respon terhadap proses pembelajaran monoton.

Blended Learning pada dasarnya merupakan gabungan keunggulan pembelajaran yang dilakukan secara tatap-muka dan secara virtual (Sevima.com: 2018). Blended learning adalah sebuah kemudahan pembelajaran yang menggabungkan berbagai cara penyampaian, model pengajaran, dan gaya pembelajaran, memperkenalkan berbagai pilihan media dialog antara guru dengan peserta didik atau murid. Blended learning juga sebagai sebuah kombinasi pengajaran langsung (face-to-face) dan pengajaran online, tapi lebih daripada itu sebagai elemen dari interaksi sosial. Blended learning merupakan pembelajaran yang didukung oleh kombinasi efektif dari cara penyampaian, cara mengajar dan gaya pembelajaran yang berbeda serta ditemukan pada komunikasi terbuka di antara seluruh bagian yang terlibat dalam pendidikan. Sedangkan untuk keuntungan dari penggunaan blended learning sebagai sebuah kombinasi pengajaran langsung (face-to-face) dan pengajaran online, dan sebagai elemen dari interaksi sosial yaitu: (1) adanya interaksi antara pengajar dan murid/peserta didik; (2) pengajaran pun bisa secara online ataupun tatap muka langsung; (3) blended learning = combining instructional modalities (or delivery media); (4) blended learning = combining instructional methods (Sevima.com: 2018).

Manfaat dari penggunaan e-learning dan juga blended learning dalam dunia pendidikan saat ini adalah $e$ learning memberikan fleksibilitas dalam memilih waktu dan tempat untuk mengakses pelajaran. Guru-guru dan peserta didik dalam pelaksanaan pengajaran nanti tidak perlu mengadakan perjalanan menuju sekolah, $e$ learning bisa dilakukan dari mana saja baik yang memiliki akses ke Internet ataupun tidak. E-learning memberikan kesempatan bagi guru-guru dan siswa/peserta didik secara mandiri memegang kendali atas keberhasilan tujuan pendidikan. Siswa/peserta didik bebas menentukan kapan akan mulai, kapan akan menyelesaikan, dan bagian mana dalam satu modul yang ingin dipelajarinya terlebih dulu. Seandainya, setelah diulang masih ada hal yang belum ia pahami, pembelajar bisa menghubungi guru melalui email, chat atau ikut dialog interaktif pada waktu-waktu tertentu. Bisa juga membaca hasil pelajaran di message board yang tersedia di LMS (Learning Management System) yang akan dibuat dalam sistem e-learning.

Jadi metode Blended Learning akan mempercepat terjadinya perubahan sosial dan budaya dalam sistem pendidikan. Karena metode pembelajaran ini akan memenuhi kebutuhan pada pengajaran di era Revolusi Industri 4.0. Dalam metode Blended Learning akan trasformasi pendidikan, di mana ada penerimaan cara-cara baru atau suatu perbaikan dalam cara suatu masyarakat memenuhi kebutuhan - kebutuhan di dunia pendidikan. Seperti guru dapat berperan membangun generasi berkompetensi, berkarakter, memiliki kemampuan literasi baru, dan keterampilan berpikir tingkat tinggi. Dengan cara bebas berinovasi dengan para 
siswa, dan dapat lebih nyaman dalam sikapi hidup, tindakan, keputusan, dan pendekatan terhadap segala jenis pengetahuan yang didasari dengan penuh kegembiraan.

Termasuk bebas dan merdeka dalam menggunakan semua media pembelajaran. Baik media cetak yaitu; buku, modul, LKS. Maupun media elektronik yaitu; video, audio, presentasi multimedia dan juga bisa menggunakan konten daring atau online. Media pembelajaran tersebut memenuhi kecenderungan pendidikan di era Revolusi Industri 4.0 yang disebut oleh Peter Fisk. Kemudian akselerasi terhadap penuntasan kopetensi utama dalam pembelajaran yaitu literasi baru dapat dipenuhi segera. Dan dalam metode Blended Learning tetap dapat membangun pendidikan karakter. Artinya selain, mewujudkan siswa atau peserta didik yang mampu berfikir kritis atau memecahkan masalah, kreatif dan inovatif, dapat berkomunikasi dan berkolaborasi, dan berkarakter. Namun juga dapat mewujudkan siswa dan peserta didik yang jujur, relegius, kerja keras/tekun, tanggung jawab, adil, disiplin, toleran, dan lain-lain. Singkatnya dalam metode ini, dapat mewujudkan tujuan sistem pendidikan merdeka belajar yaitu mewujudkan sumber daya manusia yang berkualitas dan unggul.

\section{KESIMPULAN}

Pembangunan pendidikan merdeka belajar dalam telaah metode pembelajaran yaitu sistem dan pengajarannya harus memenuhi kecenderungan dalam pendidikan di era Revolusi Industri 4.0. Di era Revolusi Industri 4.0 kebutuhan utama yang ingin dicapai dalam sistem pendidikan atau lebih khusus dalam metode pembelajaran yaitu siswa atau peserta didik yaitu penguasaan terhadap literasi baru. Literasi baru tersebut yaitu. Pertama, literasi data. Kedua, literasi teknologi. Terakhir, literasi manusia. Dan sistem dan atau metode pembelajaran pada pendidikan merdeka belajar mempunyai target yang sama. Jika perserta didik atau siswa dapat mengusai literasi baru ini, maka akan menjadi sumber daya manusia yang berkualitas dan unggul dalam membangun masa depan Indonesia. Namun selain literasi baru, sistem pendidikan merdeka belajar tetap melakukan pembangunan karakter pada peserta didik, seperti kejujuran, religius, kerja keras/tekun, tanggung jawab, adil, disiplin, toleran, dan lain-lain.

Tujuannya tentu ingin mencapai tujuan pendidikan yaitu mewujudkan murid atau peserta didik yang berfikir kritis dan memecahkan masalah, kreatif dan berinovasi, terampil berkomunikasi dan berkolaborasi, dan berkarakter. Oleh sebab itu, dalam rencana pelaksanaan kegiatan belajar harus mampu melewati tantangan dan memanfaatkan peluang pendidikan di era Revolusi Industri 4.0. Dan guru menjadi kunci keberhasilan sistem pendidikan merdeka belajar, oleh sebab itu harus dapat beradaptasi dengan sistem pendidikan yang baru agar memiliki kopetensi dan keterampilan. Penguatan literasi baru pada guru sebagai kunci perubahan, termasuk revitalisasi kurikulum berbasis literasi dan penguatan peran guru yang memiliki kompetensi digital. Maka metode Blended Learning sangat ideal sebagai metode pembelajaran di sistem pendidikan merdeka belajar. Metode pembelajarannya yaitu menggabungkan keunggulan pembelajaran yang dilakukan secara tatap-muka dan secara virtual.

\section{DAFTAR PUSTAKA}

Ahmad, Fandi. (2015). Pemikiran KH. Ahmad Dahlan tentang Pendidikan dan Implementasinya di SMP Muhammadiyah 6 Yogyakarta tahun 2014/2015. Profetika, Vol. 16, No. 2.

Ariyani, Nur Indah. (2014). Digitalisasi Pasar Tradisional Persepektif Teori Perubahan Sosial. Jurnal Analisa Sosiologi.

ER, Nur Djazifah. (2012). Modul Pelajaran Sosiologi: Proses Perubahan Sosial Masyarakat. Lembaga Penelitian dan Pengabdian Masyarakat Universitas Negeri Yogyakarta.

Ghiffar, Muhammad Alfarizqi Nizamuddin., Nurisma, Eliza., Kurniasih, Cucu., dan Bhakti, Caraka Putra. (2018). Model Pembelajaran Berbasis Blended Learning Dalam 
Meningkatkan Crtical Thinking Skills untuk Menghadapi Era Revolusi Industri 4.0. Prosiding Seminar Nasional STKIP Andi Matappa Pangkep 1 (1).

Ibda, Hamidulloh dan E Rahmadi. (2018). Penguatan Literasi Baru Pada Guru Madrasah Ibtidaiyah Dalam Menjawab Tantangan Era Revolusi Industri 4.0. JRTIE: Journal of Research and Thought of Islamic Education 1 (1), 1-21.

Lase, Delipiter. 2019. Pendidikan di Era Revolusi Industri 4.0. Jurnal Sudermann.

Putri, Aprilia Riyana dan Muzakki, Muhammad Alie. (2019). Implemetasi Kahoot Sebagai Media Pembelajaran Berbasis Digital Game Based Learning Dalam Mengahadapi Era Revolusi Industri 4.0. Kudus : Prosiding Seminar Nasional, pgsd.umk.ac.id.

Risdianto, Eko. (2019). Kepemimpinan dalam Dunia Pendidikan di Indonesia di Era Revolusi Industri 4.0. This Publication at: https://www.researchgate.net/publica tion/332423142.

Sevima.com: (2018). Pengertian dan Manfaat Pembelajaran Blended Learning. Diakses Pada 1 April 2020. (https://sevima.com/pengertian-danmanfaat-model-pembelajaranblended-learning/).

Sukardi. (2010). Metodologi Penelitian Pendidikan: Kompetensi dan Praktiknya. Jakarta: Bumi Askara.

Wulandari, Ayik., Handayani, Putri., Prasetyo, Dody Rahayu. (2019). Pembelajaran Ilmu Pengetahuan Alam Berbasis EMC (Education Mini Club) sebagai Solusi Menghadapi Tantangan Pendidikan dI Era Revolusi Industri 4.0. Thabiea 2 (1). 